\title{
Gender aspect authorities on the example of the independent management Russian empresses
}

\author{
Vasiliy Lipich, Olga Gudova* \\ Belgorod National Research University
}

\begin{abstract}
The article deals gender aspect authorities on the example of the independent management Russian empresses. They rule almost throughout eighteenth century. It was unusual for the Russian Empire. The man has always been at the head of the state. Woman led a private lifestyle. Selfexpression was possible only in a religious orientation. Women's rule has not changed the general position of women in power. The position of women in society is changed slightly. One of the achievements of the reign of empress becomes the development of culture. Architecture and music are undergoing development. Imperial court device also undergoes changes. Women of noble birth are introduced into secular society. Emperor Peter I initiated this process when he issued a decree on assemblies. During the reign of the autocratic empresses, women of the privileged class begin to head various government organizations and institutions. The lives of other women remain traditional. We studied the concepts: "gender", "gender analysis", "women's political leadership", "political participation" and historiography on the issue women's participation and representation in power structures. We meet women in power in the European tradition. Empresses received power is not legitimate. Armed uprisings brought them to power. The law does not enshrine the right of women to the throne. And this precedent of female presence in power has changed little.
\end{abstract}

\section{Introduction}

Progress is ubiquitous. Modern science is developing and carries new directions. An example of this are young, but rapidly developing gender studies. The term "gender" is often interpreted as belonging to a specific sex: male or female. Theory of social constructivism introduces a substantial difference in the concept of "sex" and "gender" (Chiari and Nuzzo, 1996). This concept delimits and explains existing differences between male and female gender group not through biological and natural features, but through social processes (Zdravomyslova and Tomkina, 2015). If we consider social constructivism starting from biological determinism then society itself is the creator of gender roles. Thus,

*Corresponding author: 728461@bsu.edu.ru 
the traits inherent in a particular sex are not given to an individual from birth, but are formed in his process of socialization. This statement evokes different opinions from researchers, especially in the context of nurturing gender identity, political participation, political leadership and power relations between representatives of different gender groups. (Lipich and Mar'yasova, 2015). It should be noted, gender analysis is meaningful function of gender. It assesses social, economic and cultural differences between groups of women and men at different stages of political monitoring. The essence of gender approach is in revealing potentially different effects political programs and legislation on the studied groups (Kamenskaya, 2002). Feminist theories interpret the term gender as a specific social category, implying social relations of inequality and power. Modern feminist theories positioning that gender research becomes more complex and substantive and show power relations more structured. These changes occur in connection with the study of gender compared to other social categories that have a hierarchy. An example of this is racial division and also division into classes. The gender hierarchy is one of the most inveterate and unshakable in comparison with other hierarchical systems. Throughout the entire historical development, this system created certain gender models and participated in the formation of gender identity. At the present stage, scientists are trying to restore historical justice and fill in the missing information about the oppressed gender group. This explains the relevance and development of gender studies. Political history is the most sought-after area of gender studies, in which you can clearly see the struggle of the female gender group for civil, political and electoral rights (Kozlova, 2018). Another factor changing the understanding of gender studies is the consideration of research data through the basic component of gender inequality - forced gender binarity (Serano, 2007). Thus, gender studies are not only an analytical component, but also include the phenomenon of imperious political relations. We can observe the brightest precedents breakthrough oppressed female gender group on the example of the rule of autocratic empresses in the Russian Empire in the period from 1725 to 1796. But this phenomenon has little changed the overall situation of the female gender group. In the following sections, we examine the sources and literature on the gender aspect of power on the example of autocratic empresses in Russia. We consider the ways of their coming to power and the essential characteristics of the government that influence the political tradition.

\section{Tasks and methods of research}

In this regard, biographical or personal history acts as the most promising direction of gender studies. In general, the task of our study explore this direction in which women followed a certain pattern of behavior. This was prescribed by the norms of the traditional society. In particular, we considered those rare precedents, which go beyond these standards and broke the tradition. But women who managed to break the existing order did not ask questions about gender asymmetry. They only used the acquired influence for the realization of their own power ambitions. Russian empresses, as well as their predecessors, who were seated on the thrones of Europe and the Byzantine Empire, did not attempt to change the status of their gender group in society (Rozhkova, 2018). We used the system method. This allowed us to create a holistic view of the subject of study. We used the comparative method. This helped us to evaluate the experience of participation in the power of the Russian empresses and identified general trends in the development of reasons which led them to autocratic rule. Besides, we used the historical biographical method, whereby studied biographical research. General theoretical scientific methods such as analysis, synthesis, synthesis and analogy were also used in this work. 


\section{Studies affecting this issue}

Gender equality issue in politics and authorities touched upon in the work of ideologues Marxist direction. In the book of A. Bebel "Woman and Socialism" tells about the situation of women from primitive times to the time of the development of capitalist society (Bebel', 2018). We studied the works of F. Engels "The Origin of the Family, Private Property and the State" (Marks and Engel's, 1986), A. Kollontai "Society and Motherhood" (Kollontay, 1972), as well as the publications of K. Tsetkin (Tsetkin, 1960). British sociologist E. Giddens studied the problems of social stratification with regard to gender differences (Giddens, 1992). Z. Freud and his students brought in worthy contribution in the study of gender aspects of power. Sociology and postmodern philosophy addresses the issue of gender and power in the works of P. Bourdieu (Peters, 2012), J. Derrida (Borchert, 2006), M. Fuko (Ryklin, 1994). Derrida considers language androcentrism as a certain linguistic asymmetry by gender and connects this phenomenon with the dominance of the male gender group in other areas, such as science and power. But studies of the twentieth and twenty-first century see the dominance of phallo-centrism in a fundamentally different way. Political theories based on ideas of feminism and gender equality are appear. The USA is becoming the center of post-classical studies in philosophical and political science. We are most interested in the work of scientists dedicated women's political leadership. This category includes the following researchers: G. Lasswell (Lasswell and McDougal, 1991), M. Weber (Veber, 1990), R. Michels, G. Lebon (Stepin, 2010). We were interested in the work of K. Millett "Sexual Politics" (Millett, 2000). The author criticizes liberal feminism. She believes that equality in power structures is illusory. True gender equality will arise, when changes will occur in all areas of society. G. Spivak (Spivak, 2001) and C. Mohanty (Mohanty, 1991) support this idea. They describe the isolation of women from politics, not only by gender, but also by race. The gender aspect of leadership has been studied in the works of psychologists J. Berger, J. Bowman, D. Hunt, S. Sutton (Bern, 2001). They explore specific barriers which arise before female gender group on the way to their political leadership. V. Lenin, Z. Lilina, A. Yenukidze wrote on this issue in Russia (Prokhorov, 1978). Later, research on this issue suspended right up until the mid-fifties. New works, dedicated to women's issues and politics were created at the end of XX century and beginning of XXI century. Now a range of sciences: psychology, political science, sociology are researching this problem. In this regard, it is necessary to note the works of $\mathrm{S}$. G. Aivazova (Ayvazova, 1998), E.S. Novikova (Novikova, 1994), N.V. Kelchina (Kel'china, 2010). Research continues to develop in this area. The peculiarity of this period is interdisciplinary.

\section{Key aspects of research}

The autocratic rule of Russian empresses is an example for studying the gender aspect of power. Power belongs to women in the XVIII century.

Political tradition is formed in the minds of the people because of this. But many transformations were begun by Peter I. The accession to the throne of the empresses was a last resort, as other candidates could carry a greater threat to the state. That is, a woman became an empress only in the case of unreliability of a male candidate. The reign of empresses can be assessed differently, but thanks to their contribution, we are talking about changes not only in power structures, but also a new round of cultural development (Anisimov, 1998). The stay of the female gender group in power was of paramount importance. Since before that the role of the woman was limited even in the social sphere. Women led a private and secluded life. Self-expression was only possible in religions. And only thanks Europeanization society changes manifested in category female. Confirmation 
of this is the decree of assemblies of 1718, in which the free presence of women was permitted (Komissarenko, 2003). Moreover, in many western countries women already headed monarchies. As the main sources of the study period it should be noted memories of eyewitnesses: B. Minich (Zapiski fel'dmarshala Minikha, 1953), M Fonvizina (Boytsov, 1991), K. Manstein (Zapiski Manshteyna o Rossii, 1953).

Manstein in his memoirs characterizes the reign of Empress Anna Ioanovna and also creates historical portraits of political figures and favorites. It is difficult to speak about the autocracy of the government of Anna Leopoldovna since she rules a little time. Many of the documents describing her regency were lost. An example of the reign of Anna Leopoldovna proves the weakness of the power of the empresses. The same applies to short-term stay on the Russian throne Catherine I. The appearance of a woman in power occurs all the same by the will of men. So the first empress gained access to power thanks to the armed guard. Guardsmen will play a huge role in all coups, when women ascend to the Russian throne. It is also necessary to note the role of political figures. They were able to rise under Peter I and they did not want to change their position under another ruler. Therefore, they helped women to become empresses and hoped on the ability to actually lead the country instead of them. Anisimov highlights the reign of Elizabeth Petrovna in detail (Anisimov, 1998) He talks about the reasons for obtaining government control of the monarch of the female gender group. Elizabeth justifies the seizure of power by kinship with Peter. Besides, all the empresses positioned themselves as heads of state who played the male role, and only then as representatives of a certain sex. The reluctance to marry and leave direct heirs confirms this. Spouses and sons could overthrow them. So the Empress Elizabeth did not want to get married, and Catherine II had a difficult relationship with her son Paul. (Anisimov, 1998) Catherine II did not come to power in a legitimate way either. Favorites rallied the army and contributed to her power. But this did not prevent her from gaining a foothold in power and compare the results of their policies to the achievements of Great Peter I.

\section{Conclusion}

Thus, all Russian autocratic empresses were elevated to the kingdom by a male gender group and this decision was dictated by revolutionary, rebellious events. Women in power brought Russia to new levels of achievement in many areas. This is a new control system, culture, successful wars and expanding boundaries. After all XVIII century knew the names of women empresses, women - the president of the Russian Academy of Sciences, women writers, artistes, secular ladies. And also women who amazed society with its high spirituality, morality and self-sacrifice. But we must not forget that the role of women in the early eighteenth century was very limited. It is difficult to talk about the contribution of this gender group in the social sphere, but thanks to the autocratic empresses we can observe her presence even in the political arena. Before the accession of women empresses to the throne the functions of this gender group were limited. Publicity was banned. Selfexpression was possible only in the religious direction. And only thanks to the changes which were expressed in a certain europeanization of the whole society rules have changed for the female gender group. But global change within the scope of the problem female political leadership has not been committed even despite the fact that the stay of women empresses lasted almost a century.

\section{References}

1. Ye.V. Anisimov, Zhenshchiny na rossiyskom prestole (Norint, SPb, 1998). 
2. S.G. Ayvazova, Russkiye zhenshchiny v labirinte ravnopraviya (Ocherki politicheskoy teorii i istorii. Dokumental'nyye materialy) (ZAO «RIK Rusanova», Moscow, 1998).

3. A. Bebel'm, Zhenshchina i sotsializm (2018).

4. S. H. Bern, Gendernaya psikhologiya (Praym-Yevroznak, SPb., 2001).

5. M.A. Boytsov, So shpagoy i fakelom. Dvortsovyye perevoroty v Rossii (Sovremennik, Mosocw, 1991).

6. M.Veber, Izbrannyye proizvedeniya (Progress, Moscow, 1990).

7. A.I. Veydemeyyer, Obzor glavneyshikh proisshestviy $v$ Rossii s konchiny Petra Velikogo do vstupleniya na prestol Yelizavety Petrovny (Nauka, SPb., 1968).

8. E.P. Giddens, Stratifikatsiya i klassovaya struktura, Sotsiologicheskiye issledovaniya, 9, 112-123 (1992).

9. Zapiski Manshteyna o Rossii, Khrestomatiya po istorii SSSR, (Nauka, Moscow, 1953).

10. Zapiski fel'dmarshala Minikha, Khrestomatiya po istorii SSSR, (Nauka, Moscow, 1953).

11. Ye. A.Zdravomyslova, A. A. Tomkina, 12 lektsiy po gendernoy sotsiologii (Izdatel'stvo yevropeyskogo universiteta v Sankt-Peterburge, SPb., 2015).

12. O. L. Kamenskaya, Gendergetika - nauka budushchego. Gender kak intriga poznaniya (Rudomino, Moscow, 2002).

13. N.V Kel'china, Politicheskoye uchastiye zhenshchin: real'nost' demokraticheskogo obshchestva, Upravleniye megapolisom: nauchno-teoriticheskiy i analiticheskiy zhurnal, 4, 217-221 (2010).

14. N. N. Kozlova, Zhenskiy vopros v politicheskoy filosofii rossiyskoy konservativnoy mysli XIX - pervoy poloviny XX v, Zhenshchina v rossiyskom obshchestve, 2, 29-41 (2018).

15. A.M. Kollontay, Izbrannyye stat'i i rechi (Politizdat, Moscow, 1972).

16. S. S. Komissarenko, Kul'turnyye traditsii russkogo obshchestva (SPbGUP, SPb., 2003).

17. T.I. Lipich, Ye.A Mar'yasova, Vliyaniye gendernykh faktorov na razvitiye zhenskoy lichnosti $v$ epokhu patriarkhata, Nauchnyye vedomosti Belgorodskogo gosudarstvennogo universiteta, 8, 87-91 (2015).

18. K. Marks, F. Engel's, Izbrannyye proizvedeniya (Moscow, Politizdat, 1986).

19. E. S. Novikova, Zhenshchiny v politicheskoy zhizni Rossii, Preobrazheniye (Russkiy feministskiy zhurnal), 2, 13-18 (1994).

20. A.M. Prokhorov, Bol'shaya Sovetskaya Entsiklopediya, (Sovetskaya Entsiklopediya, Moscow, 1978).

21. N. Rozhkova, Gotov'tes' k matriarkhatu, Moskovskiye novosti (2018).

22. M. K. Ryklin, Seksual'nost' i vlast': Antirepressivnaya gipoteza Mishelya Fuko, Logos, 5, 197-206 (1994).

23. Spivak Gayyatri Chakravorti, Mogut li ugnetennyye govorit'?, Vvedeniye v gendernyye issledovaniya, 2 (SPb., Aleteyya) 649-670 (2001).

24. V.S. Stepin, A.A. Guseynov, Novaya filosofskaya entsiklopediya (Mysl', Moscow, 2010).

25. K. Tsetkin, Sotsializm pridot $k$ pobede tol'ko vmeste $s$ zhenshchinoy-proletarkoy (Gospolitizdat, Moscow, 1960).

26. D.M. Borchert, Encyclopedia of Philosophy, 6 (10) (Thomson Gale, Leningrad, 2006). 
27. G. Chiari, M. L. Nuzzo, Psychological constructivisms: A metatheoretical differentiation, Journal of Constructivist Psychology, 9, 163-184 (1996).

28. H.D. Lasswell, M.S. McDougal, Jurispundence for a Free Society: Studies in Law, Science and Policy (Nijhoff Publishers, Boston, 1991).

29. K. Millett, Sexual Politics (University of Chicago Press, Chicago, 2000).

30. C. T. Mohanty, Third World women and the politics of feminism (Indiana University Press, Bloomington, 1991).

31. J. Serano, Whipping Girl: A Transsexual Woman on Sexism and the Scapegoating of Femininity, Seal Press (2007).

32. G. Peters, The Social as Heaven and Hell: Pierre Bourdieu's Philosophical Anthropology, Journal for the Theory of Social Behaviour, 1, 63-86 (2012). 